\title{
Ethnopharmacological and Phytochemical Studies of Tridax Procumbens Linn: A Popular Herb in Ayurveda Medicine
}

\author{
Dewashish Kaushik \\ B.Tech. (Biotechnology) \\ Department of Biotechnology, \\ Faculty of Engineering and Technology, \\ Manav Rachna International Institute of Research \& \\ Studies, Faridabad, Haryana, India
}

\author{
Alokit Tanwar \\ B. Tech. (Biotechnology) \\ Department of Biotechnology, \\ Faculty of Engineering and Technology, Manav Rachna \\ International Institute of Research \& Studies, Faridabad, \\ Haryana, India
}

\author{
Dr. Joseph Davis \\ Professor-Biotechnology \\ Department of Biotechnology, \\ Faculty of Engineering and Technology, \\ Manav Rachna International Institute of Research \& Studies, \\ Faridabad, Haryana, India
}

\begin{abstract}
Tridax procumbens (T. procumbens) Linn. is a medicinal plant found in tropical, sub-tropical and mild temperate regions around the world being used in Ayurveda treatment for liver disorders, boils, blisters, cuts, wound healing and as an anticoagulant, antifungal, and insect repellent. The plant is known to contain flavonoids, alkaloids, carotenoids, hydroxycinnamates, lignans, benzoic acid derivatives, phytosterols and tannins. The plant is also associated with endophytes to produce secondary metabolies by endophytes possessing antibacterial and antifungal activities. Different parts of this plant and essential oil are associated with ethnopharmacological properties like wound healing, antibacterial, immunomodulation, antiinflammatory, antidiabetic, vasorelaxant, antihyperlipidemic, anticancer, antiplasmodial, anticoagulation and antihepatic. Most of these studies validate the concept of earlier claims that T. procumbens's potential as a medicinal plant. Further studies are required to unravel other pharmacological activities as well as the target-based mechanism of actions. The review also highlights the need for exploring lead molecules from these myriad of compounds that are of vital importance in drug discovery strategies.
\end{abstract}

Keywords: Tridax procumbens, Wound healing, Antiinflammatory, Immunomodulatory, Metabolic syndrome, Cancer, Hepatoprotection, Antiparasitic, Antibacterial, Bone homeostasis modulators.

\section{INTRODUCTION}

T. procumbens Linn., though a native of tropical America is also found in India, tropical Africa, Asia, Australia and India as a creeper weed. T. procumbens has been traditionally used in Ayurveda system for centuries and possesses different pharmacological properties including wound healing, anti-oxidant, antibacterial, antifungal, immunomodulatory, antiinflammatory, antidiabetic, vasorelaxant, antihyperlipidemic, analgesic, antiplasmodial, anticoagulation and antihepatic [1]. The diverse biological activities are due to various phytochemicals present in the plant. The aim of this review is to critically evaluate $T$. procumbens as an important medicinal plant with emphasis on the in-vivo properties of the phytochemicals and their roles in signalling pathways that can be manipulated for specific pharmacological actions

\section{METHODS}

For the review, articles were extracted in Pubmed Central search engine using the key word Tridax Procumbens. In addition, phytochemicals, pharmacology, clinical trials, Flavanoids, Kaempferol, Catechins, alkaloids, antidiabetic, anti-inflammatory, immunomodulatory, antimicrobial, hepatoprotection, antiparasitic and bone homeostasis were also added to the search window to extract all relevant articles pertaining to Tridax Procumbens.

\section{BOTANICAL DESCRIPTION}

The taxonomical classification of T. procumbens $\mathrm{L}$. is shown in Table 1. 


\begin{tabular}{|c|c|}
\hline Kingdom & Plantae \\
\hline Sub-Kingdom & Tracheobionta \\
\hline Division & Spermatophyte \\
\hline Sub-division & Magnoliophyta \\
\hline Class & Magnoliopsida \\
\hline Sub-class & Asteridae \\
\hline Order & Asterales \\
\hline Family & Araceastee \\
\hline Genus & Tridax \\
\hline Species & procumbene \\
\hline
\end{tabular}

Table 1. Taxonomic classification of T. procumbens L.

The plant has an average height of around $20-60 \mathrm{~cm}$ and is branched. Leaves are 4-8 $\mathrm{cm}$ long, simple, opposite and stipulate. Inflorescence is around $12-32 \mathrm{~cm}$, oval shaped and held by peduncle, with ray florets and disc florets. Flowers are daisy like with yellow centred white or yellow petals. Numerous, tubular disc florets are surrounded by a ring of short, strap-shaped ray florets. Fruit is cypsela, black or brown in colour at maturity and surrounded with feathery bristles [2]. The stem is cylindrical and covered with hairs of about $1 \mathrm{~mm}$ with tap root system [3]. The registered number of chromosome present in Tridax are 36 (2n) [4]. Growth of plant takes place during monsoon season as it requires abundant water for growth and sustenance.

\section{PHYTOCHEMICAL CONSTITUENTS}

The leaf and other parts of T. procumbens L. are reported to have flavonoids, alkaloids, carotenoids, hydroxycinnamates, lignans, benzoic acid derivatives, phytosterols, tannins, crude proteins, crude fiber, soluble carbohydrates and calcium oxide [5]. The presence of fumaric acid, $\beta$-sitosterol and the pentacyclic triterpenoid oleanolic acid have also been reported [5]. Luteolin, glucoluteolin, quercetin, and isoquercetin have been reported in flower extracts [6]. Some of the other phytochemicals present abundantly in $\mathrm{T}$. procumbens are 2,6-dihydroxyacetophenone, 2-O- $\beta$-D-glucopyranoside, echioidinin, pinostrobin, dihydroechioidinin, tectochrysin-5-glucoside, methyl salicylate glucoside, 5,7,8-trimethoxyflavone, skullcapflavone-2-methyl ether, androechin, tectochrysin, 5,7,2'-trimethoxyflavone, echioidin, skullcapflavone ii, 5,7-dimethoxyflavone and andrographidine [6].

\subsection{Flavonoids}

A recent study has demonstrated the presence of twenty three flavonoids in T. procumbens [7] with total content around 65 $\mathrm{g} / \mathrm{kg}$. Kaempferol and catechin and its derivatives (-)-epicatechin, (+)-catechin, (-)-eigallocatechin, (+)-gallocatechin, (-)epigallocatechin-3-gallate (EGCG) and (-)-epicatechin-3-gallate) account for about $17.59 \%$ and $26.3 \%$ respectively. The remaining $56.11 \%$ represent sixteen flavonoids namely biochanin, apigenin, naringenin, daidzein, quercetin, butein, robinetin, baicalein, nobiletin, genistin, ellagic acid, luteolin, myricetin, baicalin, isorhamnetin and silymarin (Figure 1 and 2) [7]. 
<smiles>Oc1cc(O)c2c(c1)OC(c1ccc(O)c(O)c1)C(O)C2</smiles><smiles>O=C(/C=C/c1ccc(O)c(O)c1)c1ccc(O)cc1O</smiles>

Butein<smiles></smiles>

1. $8,3^{\prime}$-dihydroxy-3,7,4'-trimethoxy-6-0- $\beta$-D glucopyranosyl flavone 2. $6,8,3^{\prime}$-trihydroxy-3,7,4'-trimethoxyflavone<smiles>O=c1cc(-c2ccc(O)cc2)oc2c3c(ccc12)OC1CCC3CC1O</smiles><smiles>O=c1ccc2cc(O)c(O)cc2o1</smiles>

Esculetin<smiles>C=C(C)C1CCC2(C(=O)O)CCC3C(CCC4C3CCC3(C)C(C)(C)CCC43C)C12</smiles>

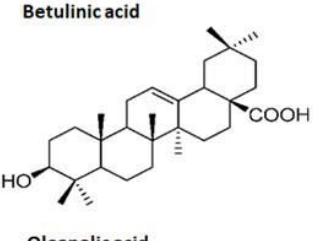

Oleanolic acid

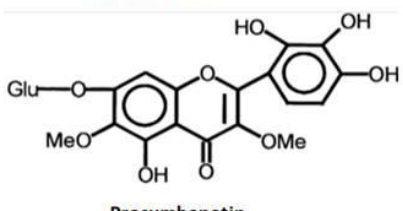

Figure 1. Structures of some flavanoids identified in T. procumbens<smiles>O=c1cc(-c2ccc(O)cc2)oc2cc(O)cc(O)c12</smiles>

Apigenin<smiles>O=c1c(O)c(-c2ccc(O)c(O)c2)oc2cc(O)cc(O)c12</smiles>

Quercetin<smiles>O=C1CC(c2ccc(O)cc2)Oc2cc(O)cc(O)c21</smiles>

Naringenin<smiles>O=c1c(-c2ccc(O)cc2)coc2cc(O)cc(O)c12</smiles>

Genistein<smiles>O=c1c(-c2ccc(O)cc2)coc2cc(O)ccc12</smiles>

Daidzein<smiles></smiles>

Ellagic acid<smiles>O=c1cc(-c2ccc(O)c(O)c2)oc2cc(O)cc(O)c12</smiles>

Luteolin<smiles>O=c1c(O)c(-c2cc(O)c(O)c(O)c2)oc2cc(O)cc(O)c12</smiles>

Myricetin<smiles>COc1ccc(C2Oc3c(O)cc(C4Oc5cc(O)cc(O)c5C(=O)C4O)cc3C2O)cc1O</smiles>

Silymarin

Figure 2. Other flavonoids present in T. procumbens

The flavonoids detected in T. procumbens are known to mediate pharmacological activities including free radical scavenging, antiinflammatory, antiallergic, antiplatelet aggregation, antimicrobial, antiulcer, antiviral, antitumor and antihepatotoxicity [8]. Two new flavones, 8,3'-dihydroxy-3,7,4'-trimethoxy-6- $O-\beta$-D-glucopyranosylflavone and 6,8,3'-trihydroxy-3,7,4'trimethoxyflavone were isolated from the whole plant along with four known compounds puerarin, esculetin, oleanolic acid and betulinic acid (Figure 1) exhibiting antioxidant activity [9]. A new flavonoid procumbenetin, from the aerial parts of $T$. procumbens, has been characterized as 3,6-dimethoxy-5,7,2',3',4'-pentahydroxyflavone 7-O- $\beta$-D-gluco-pyranoside based on spectroscopic techniques and by chemical means [10].

Kaempferol is the main flavonoid found in the leaves of $T$. procumbens L [7], the structure of which is shown in Figure 1. Preclinical studies have shown that kaempferol and its glycosidic derivatives exhibit wide range of medicinal properties such as antioxidant, analgesic, antiinflammatory, antimicrobial, antifungal, anticancer, cardioprotective, neuroprotective, hepatoprotective, antidiabetic, hypocholesterolemic, hypotriglyceridemic, antiosteoporotic, estrogenic/antiestrogenic, anxiolytic and antiallergic activities (11-14). Kaempferol has many beneficial effects on inflammatory diseases by mediating antiinflammatory or immunomodulatory activities. It inhibits various signalling pathways and suppresses matrix degrading enzymes (Table 2). 


\begin{tabular}{|c|c|c|}
\hline $\begin{array}{l}\text { Anti-inflammatory } \\
\text { Disease }\end{array}$ & Mode of Action & References \\
\hline $\begin{array}{l}\text { Intervertebral Disc } \\
\text { Degeneration (IVD) }\end{array}$ & $\begin{array}{l}\text { Inhibition of lipopolysaccharide(LPS) } \\
\text { induced apoptosis, chondrogenic } \\
\text { markers (collagen II, SOX-9 and } \\
\text { aggrican), matrix degrading enzymes and } \\
\text { lipid anabolism associated genes }\end{array}$ & 15 \\
\hline Osteoarthritis & Inhibition of NF-kB signaling pathway & 16 \\
\hline Colitis & Inhibition of NF-kB signaling pathway & 17 \\
\hline Mastitis & $\begin{array}{l}\text { Suppression of myeloperoxidase (MPO), } \\
\text { IL-6, TNF- } a \text { and ANGPTL2 expression }\end{array}$ & 18 \\
\hline Rheumatoid Arthritis & $\begin{array}{l}\text { Inhibition of fibroblast like synoviocytes } \\
\text { (FLS) by blocking mitogen activated } \\
\text { protein kinase (MAPK) pathway without } \\
\text { affecting TNF- a receptors }\end{array}$ & 19 \\
\hline Allergic asthma & Suppression of eosinophil infiltration & 20 \\
\hline Mucus Hypersecretion & $\begin{array}{c}\text { Disturbance of Transforming growth } \\
\text { factor } \beta \text { (TGF- } \beta \text { ) and ER stress signaling } \\
\text { of inositol requiring enzyme } 1 \alpha / T N F \\
\text { receptor associated factor } 2 / \mathrm{c} \text {-JuN- } \\
\text { terminal kinase (JNK) } \\
\end{array}$ & 21 \\
\hline Gastric Ulcer & $\begin{array}{l}\text { Inhibition of neutrophil accumulation, } \\
\text { MPO activity and inflammatory cytokines; } \\
\text { improves NO production }\end{array}$ & 22 \\
\hline
\end{tabular}

Table 2. Antiinflammatory mechanisms of kaempferol on inflammatory diseases

Studies have shown a positive link between dietary kaempferol and reduction in risk of chronic diseases including cancer [11]. At the molecular level, kaempferol can modulate many important elements in cellular signal transduction pathways in apoptosis, metastasis, angiogenesis and inflammation [15-23]. Epicatechin, exists in (+)-catechin and (-)-epicatechin (cis) forms (Figure 3). (-)-Epicatechin has antioxidant property due to its ability to neutralize reactive oxygen species (ROS) in the cell. It also modulates cell signalling including the mitogen-activated protein kinase pathway involved in cell proliferation [24].<smiles>O=c1c(O)c(-c2ccc(O)cc2)oc2cc(O)cc(O)c12</smiles>

(-) - Epicatechin<smiles>Oc1cc(O)c2c(c1)OC(c1ccc(O)c(O)c1)C(O)C2</smiles>

$(+)$ - Catechin<smiles>Oc1cc(O)c2c(c1)OC(O)C(c1cc(O)c(O)c(O)c1)C2</smiles>

(-)-Epigallocatechin<smiles>O=C(OC1Cc2c(O)cc(O)cc2O[C@H]1c1cc(O)c(O)c(O)c1)c1ccccc1</smiles>

(-)- Epigallocatechin gallate (EGCG)<smiles>O=C(O)C1Cc2c(O)cc(O)cc2OC1c1ccc(O)c(O)c1</smiles>

(-)-Epicatechin-3-gallate<smiles>Oc1cc(O)c2c(c1)O[C@H](c1cc(O)c(O)c(O)c1)CC2O</smiles>

(+)-Gallocatechin

Figure 3. Catechin and its derivatives reported in T. procumbens

(+)-Catechin can attenuate inflammatory responses triggered by TNF- $\alpha$ by inhibiting the gene expression of proinflammatory cytokines IL-1 $\alpha$, IL-1 $\beta$, IL-6, IL-12p35, and inflammatory enzymes like inducible nitric oxide synthase (iNOS) and cyclooxygenase-2 (COX2), and also by enhancing the gene expression of antiinflammatory cytokines including IL-4 and IL-10. (+)-Catechin also inhibits the activation of inflammatory signalling mediated by nuclear factor (NF- $\mathrm{KB}$ ), AMP activated protein kinase (AMPK), forkhead box O3a (FOXO3a) and sirtuin1 (SIRT1) [25]. Inflammation is considered a central component of allergies and considered life threatening during conditions like anaphylactic shock [26]. Reports have suggested the pharmacological effects of (-)-epicatechin during allergic immune response. When ovalbumin-challenged mice were fed with pellets containing $1 \%, 0.3 \%$, or $0.01 \%$ purified $(-)$-epicatechin for 8 days, reduction in clinical symptoms were reported including scratching around the nose or head, diarrhoea, together with reduction in ovalbumin-specific IgE levels [27]. Studies 
have shown that EGCG, a derivative of catechin can reduce the effects of food allergen ovalbumin by interacting with its secondary $\beta$ sheet structure thereby preventing uptake by antigen presenting cells [28].

\subsection{Alkaloids}

A recent study by Ikewuchi et al demonstrated that the total alkaloid content in the leaves of $T$. procumbens L were 102.421 $\mathrm{g} / \mathrm{kg}$ and $10.191 \mathrm{~g} / \mathrm{kg}$ of dry and wet weight respectively (Fig. 4).

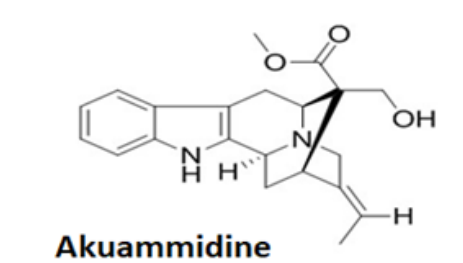<smiles>O=C(O)/C=C/c1ccc(O)c(O)c1</smiles>

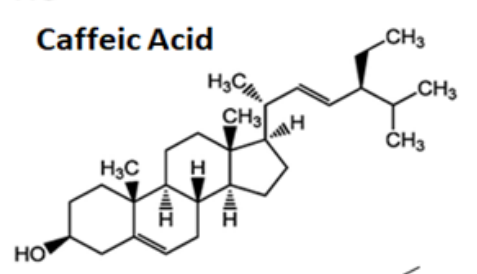

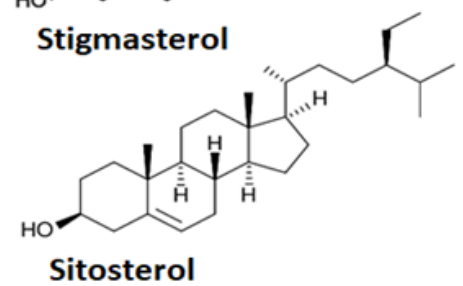

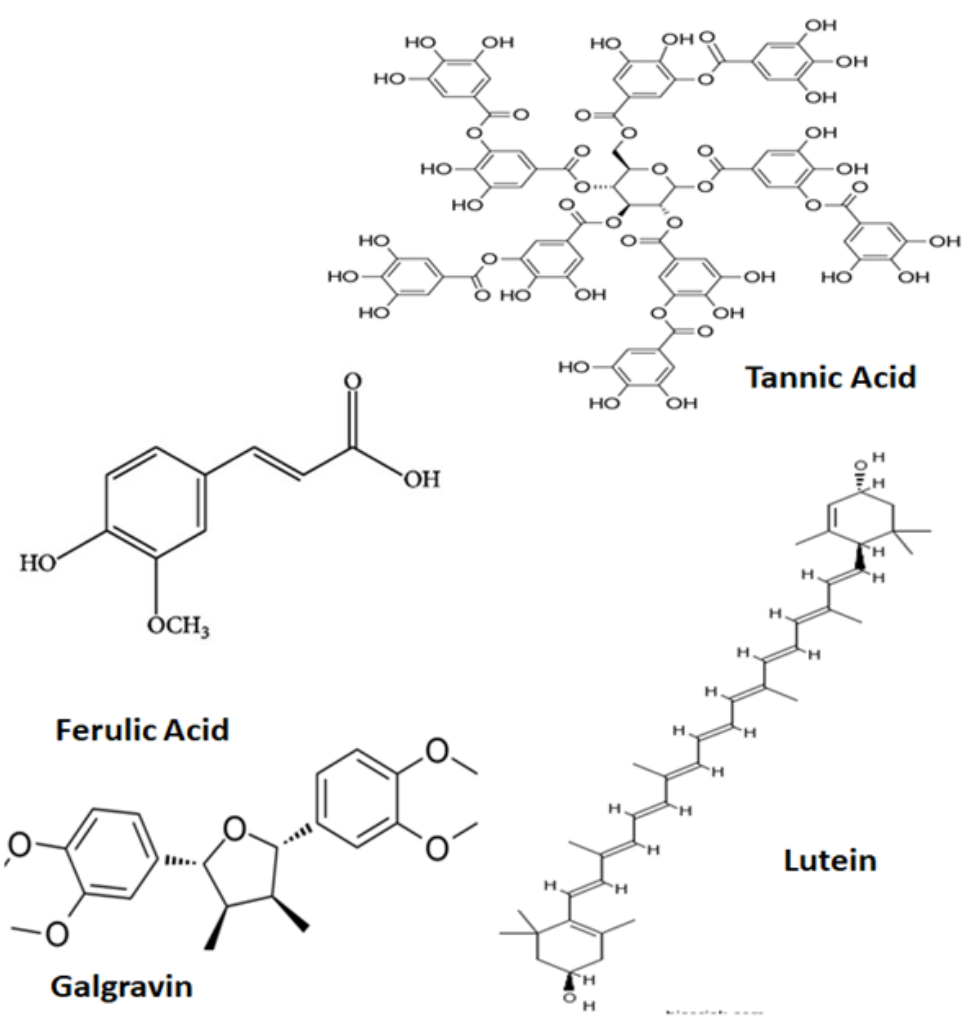

Galgravin

Figure 4. Other phytochemicals present in T. procumbens

Akuammidine is known to have biological activities such as antibacterial, antifungal, antimalarial, antiinflammatory, hypotensive, skeletal muscle relaxant, local analgesic and anti-depressant [7]. Other studies also confirmed the presence of different alkaloids in the leaves of $T$. procumbens L [29,30]. These alkaloids have been isolated using different solvents like chloroform and methanol and using different methods such as infused and decoction in a qualitative manner [29,30].

\subsection{Other phytochemicals}

The other bioactive molecules in the leaves of $T$. procumbens include caffeic acid, ferulic acid, tannins, stigmasterol and lutein [7, 29, 30]. In vitro studies have shown that caffeic acid and ferulic acid have antioxidant, antiinflammatory, anticancer and antimicrobial activities [31,32]. Tannic acid and other hydrolysable tannins have multiple health benefits including reduced risk of cardiovascular disease, anticancer, antidiarrheal, antiobesity, antibacterial, antiviral, antifibrotic and neuroprotection [33,34]. One of the molecular mechanisms attributed to tannin's health benefits is the inhibition of $\mathrm{Ca}^{2+}$-activated $\mathrm{Cl}^{-}$channels [34]. Stigmasterol has pharmacological activities such as antiosteoarthritic, antihypercholestrolemic, cytotoxicity, antitumor, hypoglycaemic, antimutagenic, antioxidant, antiinflammatory and analgesic [35]. Lutein, a type of xanthophyll carotenoid has beneficial effects against age-related macular degeneration (AMD), age-related cataract (ARC), ischemic/hypoxia induced retinopathy, light damage of the retina, retinitis pigmentosa, retinal detachment, uveitis and diabetic retinopathy [36], lung and breast cancers, heart disease and stroke [37].

\subsection{Wound healing activity}

\section{PHARMACOLOGICAL PROFILE OF T. PROCUMBENS}

Traditionally, the juice from leaves of $T$. procumbens has been used for healing dermal wounds. Wound healing process involves three phases namely inflammation, angiogenesis and collagen deposition. In an excision and incision wound model in Wistar rats, both aqueous and ethanolic extracts of T. procumbens increased the tensile strength of the wound compared to control rats. Further, wound healing biomarkers such as hydroxyproline, collagen and hexosamine were significantly increased [38]. The wound healing ability was also confirmed by topical ointment formulation of the leaf extract of T. procumbens in a mouse model, where dose-dependent improvement of cell proliferation and wound remodelling was observed [39]. Lysyl oxidases (LOX) are a group of enzymes catalyzing cross-linking reaction of collagen and elastin to form covalently linked, 
insolubilize extracellular matrix (ECM) proteins thereby facilitating ECM stabilization through ECM formation, development, maturation and remodelling [40]. The increased lysyl oxidase activity on treatment with $T$. procumbens extract in rat wound healing model suggests their role in wound healing [41]. In C. elegans wound model and cell lines scratch wound healing assay, the wound healing ability of $T$. procumbens and its phytocompounds Octa decenoic acid (ODA), Pyridine carboxamide oxime, known as Nicotinamide (NA) and Dimethyl Benz[c]acridine (DMB) were studied. Results indicated that the wound healing ability was mainly contributed by NA in the chloromethyl nicotinamide derivative form by interacting with the wound healing biomarker, glycogen synthase kinase 3 (GSK-3) [42].

\subsection{Antiinflammatory Activities}

Since, inflammation is one of the three phases of wound healing, T. procumbens was evaluated for its antiinflammatory potential. An earlier study showed that aqueous extract of T. procumbens exhibited a dose dependant inhibition of paw volume in carrageenan induced rat paw edema and cotton pellet granuloma model as well as significant reduction in cell migration compared to control [43]. In another study, T. procumbens was shown to possess dose dependent analgesic activities in formalin, acetic acid and complete Freund's adjuvant (CFA)-induced pain models. These protective actions against pain may be attributed to flavonoids and sterols present in the extract and have the potential to develop effective analgesics [44]. The antiinflammatory activities of $T$. procumbens were further corroborated in an in vivo carrageenan-induced rat paw edema model in which standardized EtOAc, $\mathrm{MeOH}$ and $70 \% \mathrm{EtOH}$ extracts of T. procumbens aerial parts displayed anti-inflammatory potential at a median dose of $200 \mathrm{mg} / \mathrm{kg}$ with maximum activity by EtOH fraction comparable to the control ibubrufen at 100 $\mathrm{mg} / \mathrm{kg}$ (\% inhibition of paw edema at 5 h: $41.2 \pm 2.2$ vs. $52.2 \pm 1.5)$ [45]. The EtOAc extract exhibited strong antioxidant activity against 1,1- diphenyl-2-picrylhydrazyl (DPPH) and 2,2'-azino-bis (3-ethylbenzthiazoline-6-sulfonic acid) (ABTS) free radicals and COX1 (Cyclooxygenase 1) and COX2 (Cyclooxygenase 2) inhibitory activities compared to $\mathrm{MeOH}$ and $70 \% \mathrm{EtOH}$ extracts which may be attributed to the flavonoids and other polyphenols present in the extracts [45]. In a similar study, antiinflammatory activities were demonstrated in carrageenan induced mouse model where improved inflammation in histopathological scoring of mice paw, decreased gene expression of TNF- $\alpha$ and COX2 in mouse paw treated with EtOH extract of $T$. procumbens were observed compared to control [46].

\subsection{Immunomodulatory Activities}

The ability of bioactives in modulating immune response to ameliorate certain diseases reflects its biological or pharmacological effects on humoral or cellular immune response [47]. Intraperitoneal injection of an aqueous extract of $T$. procumbens Linn. (TPEIF) in Swiss male albino mice exhibited significant increase in immunomodulatory indexes such as phagocytic index, leucocyte count, splenic antibody secreting cells and augmentation of both humoral and cellular immune response as evidenced by elevation of heamagglutination antibody titer and delayed type hypersensitivity reaction respectively [48]. Further, the aqueous extract protected against anaphylactic shock in mice sensitized with $1 \mathrm{mg}$ bovine serum albumin with reduction in number of animals presenting anaphylactic symptoms. The overall immunomodulatory responses may be due to the presence of the sesquiterpene and terpenoids in the aqueous extract. The detection of a specific antibody to tetanus toxoid (TT) in TPEIF treated animals showed significant stimulation of specific antibodies against TT suggesting a role for aqueous extract of $T$. procumbens Linn. in immuno-compromised patients and as a vaccination adjuvant to reduce the number of nonresponders to vaccines [48]. In another study, oral administration of methanol extract, chloroform fraction (CFTP), ethyl acetate fraction (EFTP), n-Butanol fraction (NFTP) and remnant water soluble fraction (RWSFTP) fractions in Swiss Albino Mice (20$40 \mathrm{mg} / \mathrm{kg}$ body weight) exhibited positive response in stimulating immune responses. Notably, EFTP and NFTP fractions rich in flavonoids and triterpenoidal saponin modulated both cell mediated and humoral components of the immune system [49]. Furthermore, ethanolic extract of T. procumbens stimulated humoral response in Swiss albino Rats and phagocytosis and also conferred protection against Pseudomonas aeruginosa infection [50].

\subsection{Antimicrobial Activity}

Bioactives from plants are used in traditional therapies as antimicrobials [51]. Aqueous extracts from different plants including T. procumbens possess antimicrobial activities $[52,53]$. T. procumbens extract exhibited antibacterial activity against clinically relevant Gram positive and Gram negative bacteria [54-58]. In one study, T. procumbens crude extract of n-hexane was active against pathogens like Mycobacterium smegmatis, Klebsiella species and Salmolella species whereas ethyl acetate extract was active against Mycobacterium smegmatis and S. aureus. These differential antibacterial activities may be due to the presence of mixture of hydrocarbons in n-hexane extracts such as neophytadiene and long chain fatty acids such as hexadecanoic acid. In the case of ethylacetate extract, fatty acids, aromatic compounds, polyaromatic carboxylic acids, polysubstituted phenols and thiols were reported [54]. T. procumbens leaves extracted in different solvents exhibited antibacterial activities. Chloroform extract was effective against $B$. faecalis and $E$. coli, the ethanolic extract was moderately active against $B$. faecalis whereas petroleum ether extract was active against $B$. faecalis. This study suggested that tannins in chloroform extract and alkaloids in petroleum ether and ethanol extracts were responsible for the antimicrobial activities [55]. Though, the ethanolic extracts of $T$. procumbens were reported to have antibacterial activity by many researchers $[55,56]$, Saritha et al. have reported no antibacterial activity in whole plant extract which could be due to lower concentration of the actives [57]. Methanolic leaf extract of $T$. procumbens from one study inhibited $S$. aureus causing bovine mastitis [58] suggesting that there is wide range of antibacterial activities possessed by this plant. Efforts were also made to prepare nanoparticles from the leaf of $T$. procumbens. 
The silver nanoparticles prepared from the callous extracts of stem and leaf of the plant exhibited some activity against $E$. coli, $V$. cholerae, A. niger, and A flavus [59] and $\mathrm{Cu}_{2} \mathrm{O}$ nanoparticles [60] against E. coli. More investigations are needed to improve this technology.

It has been documented that endophytic microorganisms including fungi or bacteria results in the production of antifungals such as pseudomycins, ecomycins [61,62] and antibacterials such as indolosesquiterpenes compounds [63]. Fungal or bacterial endophytes (BEs) are considered as potential sources of novel antibiotics. In a recent study, improvement of experimentally induced dermatophytic lesions by $T$. procumbens plant extract suggests the presence of antifungal principle to cure dermatophytosis [64]. Further, the plant is also known for its antibacterial properties [65, 66]. Analysis of fifty novel endophytes from the leaves and stems of T. procumbens revealed the association of Bacillus spp., Cronobacter sakazakii, Enterobacter spp., Lysinibacillus sphaericus, Pantoea spp., Pseudomonas spp. and Terribacillus saccharophilus with the plant [67]. Bacterial endophytes associated with roots of $T$. procumbens can be used for bioremediation of heavy metals [68]. Fungal endophytes in association with T. procumbens have been reported to have antibacterial activity. In an experimental study, out of six endophytic fungi (TP-1 to TP-6) isolated from the leaves of the T. procumbens, TP-1 identified as Alternaria sp. exhibited maximum antibacterial activity against Escherichia coli, Salmonella Typhi, Bacillus sp., Pseudomonas aeruginosa, Staphylococcus aureus and klebsiella pneumonia [69].

\subsection{Life Style Diseases and T. procumbens}

Metabolic syndrome (MetS) is a cluster of metabolic abnormalities having three of five clinical criteria: obesity, dyslipidemia, low serum HDL cholesterol, hypertension and hyperglycemia [70]. Genetic factors, acquired factors, sedentary life style and dysregulated endocrine signalling are primary contributors of MetS [71]. As per American Heart Association (AHA), treatment involves multiple pharmacological interventions to adequately correct the individual risk factors [72]. Natural products are important source of therapeutically effective drugs with more than $80 \%$ of world's population depending on plants [73]. FDA (Food and Drug Administration)-approved drugs has revealed that derivatives of natural products represent one-third of the total approved New Molecular Entities (NMEs) of which 50\% are from mammals, 25\% each from microbes and plants [74].

The antidiabetic activities of $T$. procumbens were documented in various animal models [75-78]. Oral administration of whole plant methanolic extract of $T$. procumbens in alloxan-induced diabetic rats showed a significant decline in fasting blood glucose without much effect on body weight reduction and toxicity [75]. Antidiabetic activity was reported when another aqueous and alcoholic extracts of the leaves of $T$. procumbens were tested in alloxan-induced diabetic rats [76]. Administration of ethanolic extract of $T$. procumbens (whole plant) at 250 and $500 \mathrm{mg} / \mathrm{kg}$ in streptozotocin-nicotinamide induced Wistar rats have demonstrated significant reduction of blood glucose, serum cholesterol, triglycerides, and LDL- cholesterol compared to the standard anti-diabetic drug glibenclamide at $0.25 \mathrm{mg} / \mathrm{kg}$. Other favourable pharmacological profiles such as increased HDLcholesterol and body weight reduction indicated that standardized extracts of $T$. procumbens alone or in combination with other herbal extracts may be an excellent choices to treat MetS [77,78]. Polyherbal formulation may bring additive or synergic effects in their pharmacological responses against MetS which were not explained [78]. Ali et al [79] reported that oleanoic acid and its derivatives are inhibitors of $\alpha$-glucosidase with $\mathrm{IC}_{50}$ as low as $7.97 \pm 0.214 \mu \mathrm{M}$. Inhibition of $\alpha$-glucosidase slows the breakdown of carbohydrate, enhances its utilization, lowers insulin levels and maintains glucose homeostasis. In one study, ether, methanol, and chloroform extracts of $T$. procumbens exhibited a significant reduction of $\alpha$-glucosidase which may be due to oleanoic acid derivatives $[79,80]$. In a clinical study, when aqueous whole plant $T$. procumbens extract was administered for 4 weeks along with prescribed medications to type 2 diabetics, significant lowering of fasting and postprandial blood glucose was observed [81].

Since hypertension $(50-75 \%)$ and obesity $(30-50 \%)$ are co-morbid conditions in type 2 diabetics [82], phytotherapeutic intervention is ideal to treat more than one condition of MetS. When $20 \mathrm{mg} / \mathrm{kg}$ of $N$-nitro-L-arginine methyl ester (L-NAME)induced hypertension rats were treated with aerial parts of $T$. procumbens extracts prepared in different solvents (cyclohexane, micellar, dichloromethane and ethyl acetate) for seven days, ethyl acetate and dichloromethane fractions were most effective in lowering the mean arterial pressure of rats comparable to the standard ACE inhibitor captopril. The hypotensive effects of these fractions may be due to the enriched alkaloids and flavonoids and the probable vasorelaxation effect of flavanoids [83]. The mechanisms of vasodilation of $T$. procumbens extract include blocking or modulating cGMP and cAMP in rat aorta artery [84], blocking $\mathrm{Ca}^{2+}$ channels, stimulation of prostacyclin production and opening of small-conductance $\mathrm{Ca}^{2+}$ activated potassium channels in rat superior mesenteric arteries [85] and by the release of NO from endothelium of rat smooth muscle [86].

\subsection{Anticancer Activity}

T. procumbens flower crude aqueous and acetone extracts when tested against prostate epithelial cancerous cells PC3 in MTT assay, the former demonstrated anti-cancer activity [87]. Sankaranarayanan S. et al. [88] have isolated a compound Lupeol which inhibited cell viability of human lung cancer cell A-549 in MTT assay upto $90 \%$. Further, this compound at $320 \mu \mathrm{g} / \mathrm{ml}$ concentration showed anti-cancer potential in various assays namely colonogenic survival determination, cell cycle control, cell based assay for inhibition of COX-2 activity and DNA fragmentation analysis [88]. The essential oil of T. procumbens $\mathrm{L}$ 
significantly prevented B16F-10 cell line-mediated lung metastasis in C57BL/6 mice along with prevention of tumor directed angiogenesis and induction of apoptosis [89]. The crude aqueous extract of $T$. procumbens when nanoformulated with poly (vinyl pyrrolidone) exhibited superior anticancer, antioxidant and antiinflammatory activity suggesting an effective strategy to enhance therapeutic index [90].

\subsection{Hepatoprotective Activity}

Drug-induced liver injury (DILI) or drug-induced hepatotoxicity is caused by all classes of drugs, herbal and dietary supplements. Specific examples of drug classes include anaesthetics (halothane), non-steroidal anti-inflammatory drugs (diclofenac), antibiotics (rifampicin, beta lactam antibiotics such as penicillin and cephalosporin), antifungals (ketoconazole), highly active antiretroviral therapy (HAART), oral hypoglycemics (PPAR- $\gamma$ agonists like troglitazone, rosiglitazone, sulfonylureas such as glimepiride) and lipid lowering drugs (statins and ezetimibe) [91]. The mechanisms of DILI include inhibition of mitochondrial respiratory chain, increased generation of reactive oxygen species (ROS), ATP depletion, triggered apoptosis and immune mediated injury [91]. Though, the global use of herbal therapy for hepatotoxicity is increasing, evidence suggests that these may also cause hepatotoxicity. For instance, herbal toxicity is reported for Herbalife ${ }^{\circledR}$ products causing differential patterns of liver injury [92]. Thus, phytotherapies to counter hepatotoxicity need a cautious approach.

The oral administration of $T$. procumbens ethanolic extract at 100, 200, 300 and 400mg/kg body weight for the period of 7 days in paracetamol induced hepatotoxic male albino rats, resulted in the significant reversal of increased alanine aminotransferase, aspartate aminotransferase, serum alkaline phosphatase and enhanced lipid peroxidation. Increase in superoxide dismutase and catalase activities in liver cells suggest antioxidant and hepatoprotective efficacy of $T$. procumbens L. [93]. When petroleum ether, methanol and chloroform/water extracts were orally administered in D-galactosamine induced hepatotoxic male Wistar Albino rats, significant reduction of liver enzymes alanine transaminase (ALT) and aspartate transaminase (APT) compared to non-treated control (D-galactosamine treated rats) along with dose dependent antioxidant activities in methanolic extract compared to other fractions [94]. Hepatoprotective effects of $T$. procumbens were also demonstrated against carbon tetrachloride induced liver injury in Wistar rats [95], isoniazid-rifampicin induced toxicity in albino rats [96] and rifampicin induced hepatotoxicity in male Albino rats [97]. Hepatoprotection against experimentally induced hepatitis [98,99] by $T$. procumbens was also reported. Pretreatment of D-galactosamine/Lipopolysaccharide induced-hepatitis in rats with chloroform insoluble fraction from ethanolic extract of $T$. procumbens improved liver parameters like aspartate transaminase, alanine transaminase, alkaline phosphatase, lactate dehydrogenase, $\gamma$-glutamyl transferase, bilirubin and lipid levels both in serum [98]. In the same animal model, Ravikumar et al. demonstrated the improvement of liver antioxidant defense system such as decreased lipid peroxides, increased activities of superoxide dismutase, catalase, glutathione peroxidase, glutathione-Stransferase and the non-enzymatic antioxidants namely reduced glutathione, vitamin C and vitamin D [99].

\subsection{Bone Homeostasis Modulators}

Plant-derived flavonoids are shown to function as bone homeostasis modulators by stimulating osteoblasts function and inhibiting osteoclasts functions either alone or in combination [100]. Primary osteoclastic cells when treated with $T$. procumbens fraction (TPF), showed significant suppression of Receptor activator of nuclear factor kappa-B ligand (RANKL)-induced differentiation of osteoclasts and the formation of pits were noticed [101]. The down-regulation of osteoclast differentiation genes like Tartrate resistant acid phosphatase (Trap), Cathepsin K, Matrix metalloprotease-9 (Mmp-9), and Matrix metalloprotease-13 (Mmp-13) and proteins such as Cathepsin K, Mmp-9, and Mmp-13 in primary osteoclast cells treated with TPF suggests that TPF could be a potential anti-bone resorption agent to treat patients with bone loss associated diseases such as osteoporosis [101]. When mice were treated with TPF, bone formation related indices like bone mineral density, bone mineral content, osteoblast number, osteoblast surface, bone volume, mineralizing surface, mineral apposition rate and bone formation rate were significantly increased compared to the control mice [102]. Molecular mechanisms of inhibition of osteoclast differentiation by TPF could be due to the down-regulation of transcription factors such as c-Fos, nuclear factor of activated T cells cytoplasmic 1 (NFATc1) and activator protein-1 (AP-1) [103].

\subsection{Antiparasitic Activity}

Parasitic infections caused by protozoa, nematodes, trematodes, and cestodes account for more than $30 \%$ of the human population and the plant extracts and their secondary metabolites may be an excellent strategy to target these infections [104]. $T$. procumbens extracts have been shown to possess antiparasitic activities against Leishmania mexicana [105] and P. falciparum [106]. An active bioactive compound (3S)-16,17-didehydrofalcarinol isolated from T. procumbens exhibited significant in vitro activities against promastigotes and intracellular amastigotes of L. mexicana [105]. Oral administration of L. mexicana-infected mice with $T$. procumbens extract in combination with Allium sativum extract, known for its immunomodulatory effect, exhibited significant protection against infection as evident by improved anti-inflammatory score in mouse footpad assay and Th1-type immune response [107].

\section{CONCLUSION}

This is a comprehensive review that highlights the various phytochemicals identified in $T$. procumbens together with their diverse pharmacological attributes. Since, most of the small molecules approved by FDA are derived from plant sources, it is essential to evaluate the plant in a systematic manner to identify bioactives which could lead to the discovery and development 
of new drugs against various ailments. Though, T. procumbens has been used in many traditional medicines, scientific data relating their phytochemicals with published pharmacological properties are lacking. Many of the studies have used plant extracts followed by qualitative analysis of its phytochemical constituents. Researchers should try to employ new drug discovery principles like bio-assay guided phytochemical identification, phenotypic screening using relevant cell culture models and if possible demonstrate pharmacokinetic-pharmacodynamic correlation (PK-PD) to show the efficacy of the preparation. Attempts should also be made to identify the active metabolites mediating the in vivo efficacy to ensure standardized extract preparation. In addition, a battery of enzyme targets can be identified for different diseases and the partially purified bioactives checked for inhibitors or activators. Identification of new bioactives may serve as a chemophore or pharmacophore to be developed as a drug using Molecular Modeling, Medicinal Chemistry and Bioinformatics approaches. Since, T. procumbens is reported to have many pharmacological properties, researchers should try to evaluate their properties using modern technologies.

\section{ACKNOWLEDGEMENTS}

The authors are very thankful to the Department of Biotechnology, Faculty of Engineering \& Technology, Manav Rachna International Institute of Research and Studies, Faridabad, Haryana, India fo supporting this research. The authors are very thankful to Ms. Shyamala Krishnamoorthi and Dr. Rammohan Rao, Faculty, California College of Ayurveda for the critical inputs for the review.

\section{AUTHORS CONTRIBUTION}

JD supervised and critically reviewed the manuscript apart from literature search and drafting of the manuscript. DK and AT carried out the literature search, written the manuscript. All the authors read and approved the manuscript.

\section{REFERENCES}

[1] Beck S, Mathison H, Todorov T, Calderón-Juárez EA, Kopp OR. A review of medicinal uses and pharmacological activities of Tridax procumbens (L.). J Plant Sci. 2018;7:19-35.

[2] Rahman AHMM, Alam MS, Khan SK, Ahmed F, Islam AKMR, Rahman MM. Taxonomic studies on the family Asteraceae (Compositae) of the Rajshahi division. Res J Agric \& Biol Sci. 2008;4:134-140.

[3] Kumar S, Prasad A, Iyer SV, Vaidya S. Pharmacognostical, phytochemical and pharmacological review on Tridax procumbens Linn. Int J Pharm Biol Arch. 2012; 3:747-751.

[4] Xie Z, Zheng C. Cytological studies on 13 species of Compositae from Hainan, China. Acta Phytotax Sin. 2003;41:545-552.

[5] Mundada S, Shivhare R. Pharmacology of Tridax procumbens a weed. Int J Pharm Tech Res. 2010;2:1391-1394.

[6] Verma RK, Gupta MM. Lipid constituents of Tridax procumbens. Phytochemistry. 1988;27:459-163.

[7] Ikewuchi CC, Ikewuchi JC, Ifeanacho MO. Phytochemical composition of Tridax procumbens Linn leaves: Potential as a functional food. Food Nutr Sci. 2015; 6:992-1004.

[8] Dillard CJ, German JB. Phytochemicals: Nutraceuticals and human health. J Sci Food Agric. 2000;80:1744-1756.

[9] Xu R, Zhang J, Yuan K. Two new flavones from Tridax procumbens Linn. Molecules. 2010;15:6357- 6364.

[10] Ali M, Ravinder E, Ramachandram R. A new flavonoid from the aerial parts of Tridax procumbens. Fitoterapia. 2001;72:313-315.

[11] Calderón-Montaño JM, Burgos-Morón E, Pérez-Guerrero C, López-Lázaro M. A review on the dietary flavonoid kaempferol. Mini Rev Med Chem $2011 ; 11(4): 298-344$

[12] Zhou M, Ren H, Han J, Wang W, Zheng Q, Wang D. Protective Effects of Kaempferol against Myocardial Ischemia/Reperfusion Injury in Isolated Rat Heart via Antioxidant Activity and Inhibition of Glycogen Synthase Kinase-3 $\beta$. Oxidative Med. Cell. Longev 2015; Article ID 481405,8 pages, 2015. https://doi.org/10.1155/2015/481405

[13] Filomeni G, Graziani I, Zio DD, Dini L, Centonze D, Rotilio G et al. Neuroprotection of kaempferol by autophagy in models of rotenone-mediated acute toxicity: possible implications for Parkinson's disease. Neurobiol. Aging 2012; 33(4): 767-785.

[14] Ahmad M, Gilani AUH, Aftab K, Ahmad VU. Effects of kaempferol-3-O-rutinoside on rat blood pressure. Phytother Res 1993; 7(4): 314-316.

[15] Zhu J, Tang H, Zhang Z, Zhang Y, Qiu C, Zhang L, et al. Kaempferol slows intervertebral disc degeneration by modifying LPS-induced osteogenesis/adipogenesis imbalance and inflammation response in BMSCs. Int Immunopharmacol 2016; 43: 236-242,

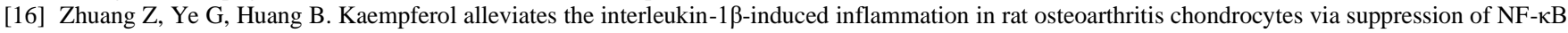
Med Sci Monit 2017; 23: 3925-3931.

[17] Salaritabar A, Darvishi B, Hadjiakhoondi F, Manayi A, Sureda A, Nabavi SF et al. Therapeutic potential of flavonoids in inflammatory bowel disease: A comprehensive review. World J Gastroenterol 2017; 23(28): 5097-5114.

[18] Cao R, Fu K, Lv X, Li W, Zhang N. Protective effects of kaempferol on lipopolysaccharide-induced mastitis in mice. Inflammation 2014; 37(5): 14531458.

[19] Pan D, Li N, Liu Y, Xu Q, Liu Q, You Y et al. Kaempferol inhibits the migration and invasion of rheumatoid arthritis fibroblast-like synoviocytes by blocking activation of the MAPK pathway. Int Immunopharmacol 2018; 55: 174-182.

[20] Gong JH, Shin D, Han SY, Kim JL and Kang YH. Kaempferol suppresses eosionphil infiltration and airway inflammation in airway epithelial cells and in mice with allergic asthma. J Nutr 2012; 142: 47-56.

[21] Park SH, Gong JH, Choi YJ, Kang MK, Kim YH, Kang YH. Kaempferol inhibits endoplasmic reticulum stress- associated mucus hypersecretion in airway epithelial cells and ovalbumin-sensitized mice. PLoS One 2015; 10: e0143526. https://doi.org/10.1371/journal.pone.0143526

[22] Li Q, Hu X, Xuan Y, Ying J, Fei Y, Rong J, et al. Kaempferol protects ethanol-induced gastric ulcers in mice via pro-inflammatory cytokines and NO. Acta Biochim Biophys Sin (Shanghai) 2018; 50: 246-253.

[23] Ren J, Lu Y, Qian Y, Chen B, Wu T, Ji G. Recent progress regarding kaempferol for the treatment of various diseases. Exp Ther Med 2019; 18(4): $2759-2776$

[24] Shay J, Elbaz HA, Lee I, Zielske SP, Malek MH, Hüttemann M. Molecular mechanisms and therapeutic effects of (-)-Epicatechin and other polyphenols in cancer, inflammation, diabetes, and neurodegeneration. Oxid. Med. Cell. Longev 2015; Article ID 181260, https://doi.org/10.1155/2015/181260

[25] Cheng AW, Tan X, SunJ Y, Gu CM, Liu C, Guo X. Catechin attenuates TNF- $\alpha$ induced inflammatory response via AMPK-SIRT1 pathway in 3T3-L1 adipocytes. PLOS ONE 2019; 14(5): e217090. https://doi.org/10.1371/journal.pone.0217090

[26] Theoharides TC, Kalogeromitros D. The critical role of mast cells in allergy and inflammation. Ann NY Acad Sci 2006; 1088: 78-99.

[27] Singh A, Demont A, Actis-Goretta L, Holvoet S, Lévêques A, Lepage M et al. Identification of epicatechin as one of the key bioactive constituents of polyphenol-enriched extracts that demonstrate an anti-allergic effect in a murine model of food allergy. Br J Nutr 2014; 112(3): 358-368. 
[28] Ognjenović J, Stojadinović M, Milčić M, Apostolović D, Vesić J et al. Interactions of epigallo-catechin3-gallate and ovalbumin, the major allergen of egg white. Food Chem 2014; 164: 36-43.

[29] Jude CI, Catherine CI, Ngozi MI. Chemical profile of Tridax procumbens Linn. Pak J Nutr 2009; 8(5): 548-550.

[30] Savithramma N, Rao ML, Bhumi G. Phytochemical screening of Thespesia populnea (L.) Soland and Tridax procumbens L. J Chem Pharm Res 2011; 3(5): 28-34.

[31] Magnani C, Isaac VLB, Correa MA, Salgado HRN. Caffeic acid: a review of its potential use in medications and cosmetics. Anal Methods 2014; 6: 3203-3210.

[32] Touaibia M, Jean-François J, Doiron J. Caffeic Acid, a versatile pharmacophore: an overview. MINI-REV MED CHEM 2011; 11(8): 695-713. DOI $10.2174 / 138955711796268750$.

[33] Scalbert A, Manach C, Morand C, Remesy C, Jimenez L. Dietary polyphenols and the prevention of diseases. Crit Rev Food Sci Nutr 2005; 45: 287306.

[34] Namkung W, Thiagarajah JR, Phuan PW, Verkman AS. Inhibition of Ca2+-activated Cl- channels by gallotannins as a possible molecular basis for health benefits of red wine and green tea. FASEB J 2010; 24(11): 4178-4186.

[35] Kaur N, Chaudhary J, Jain A, Kishore L. Stigmasterol: A comprehensive review. Int J Pharm Sci Res 2011; 2(9): 2259-2265.

[36] Jia YP, Sun L, Yu HS, Liang LP, Li W, Ding H et al. The Pharmacological effects of Lutein and Zeaxanthin on visual disorders and cognition diseases. Molecules 2017; 22(4): 610, https://doi.org/10.3390/molecules22040610

[37] Ribaya Mercado JD, Blumberg JB. Lutein and Zeaxanthin and their potential roles in disease prevention. J Am Coll Nutr 2004; 23(suppl 6): 567S-587S

[38] Yaduvanshi B, Mathur R, Mathur SR, Velpandian T. Evaluation of wound healing potential of topical formulation of leaf juice of Tridax procumbens L. in mice. Indian j Pharm Sci 2011; 73(3): 303-306

[39] Udupa SL, Udupa AL, Kulkarni DR. Influence of Tridax procumbens on lysyl oxidase activity and wound healing. Planta med $1991 ; \mathbf{5 7}(04)$ : 325-327.

[40] Udupa AL, Kulkarni DR, Udupa SL. Effect of Tridax procumbens extracts on wound healing. Int J Pharmacogn 1995; 33(1): 37-40.

[41] Talekar YP, Apte KG, Paygude SV, Tondare PR, Parab PB. Studies on wound healing potential of polyherbal formulation using in vitro and in vivo assays. J Ayurveda Integr Med 2017; 8(2): 73-81.

[42] Pooranachithra M, Bhaskar JP, Murali D, Das SS, JebaMercy G, Krishnan V, et al. Unravelling the wound healing ability and mode of action of pyridine carboxamide oxime using Caenorhabditis elegans as potential prescreen wound model. Life Sci 2019; 235: 116859.

[43] Diwan PV, Karwande I, Margaret I, Sattur PB. Pharmacology and biochemical evaluation of Tridax procumbens on inflammation. Indian J Pharmacol 1989; $21: 1-7$.

[44] Prabhu VV, Nalini G, Chidambaranathan N, Kisan SS. Evaluation of antiinflammatory and analgesic activity of Tridax procumbens Linn. against formalin, acetic acid and CFA induced pain models. Int J Pharm Pharm Sci 2011; 3(2): 126-130.

[45] Jachak SM, Gautam R, Selvam C, Madhan H, Srivastava A, Khan T. Anti-inflammatory, cyclooxygenase inhibitory and antioxidant activities of standardized extracts of Tridax procumbens L. Fitoterapia 2011; 82(2):173-7.

[46] Grace VMB, Viswanathan S, Wilson DD, Kumar SJ, Sahana K, Arbin EFM et al. Significant action of Tridax procumbens L. leaf extract on reducing the TNF- $\alpha$ and COX-2 gene expressions in induced inflammation site in Swiss albino mice. Inflammopharmacology 2020; 28(4): 929-938.

[47] Wagner H. Search for plant derived natural products with immunostimulatory activity: recent advances. Pure Appl Chem 1990; 62(7): $1217-1222$.

[48] Tiwari U, Rastogi B, Singh P, Saraf DK, Vyas SP. Immunomodulatory effects of aqueous extract of Tridax procumbens in experimental animals. $J$ Ethnopharmacol 2004; 92(1): 113-119.

[49] Agarwal S, S Khadase, G Talele. Bioactive immunomodulatory fraction from Tridax procumbens. Asian j Biol Sci 2010; 3(3): 120-127.

[50] Oladunmoye MK. Immunomodulatory effects of ethanolic extract of Tridax procumbens on swiss Albino rats orogastrically dosed with Pseudomonas aeruginosa (NCIB 950). Int J Trop Med 2006; 1(4): 152-155.

[51] Cowan MM. Plant products as antimicrobial agents. Clin Microbial Rev 1999; 12(4): 564-582.

[52] Sood S, Davis J. Anti-biofilm activity of Azadirachta indica and Ocimum sanctum aqueous extract combination against MRSA. Int J Pharm Res 2020; 12(4): 514-520.

[53] Joshi RK, Badakar V. Chemical composition and in vitro antimicrobial activity of the essential oil of the flowers of Tridax procumbens. Nat Prod Commun 2012; 7(7): 941-942.

[54] Taddei A, Rosas-Romero AJ. Bioactivity studies of extracts from Tridax procumbens. Phytomedicine 2000; 7(3): 235-238.

[55] Christudas S, Kulathivel TM, Agastian P. Phytochemical and antibacterial studies of leaves of Tridax procumbens L. Asian Pac J Trop Biomed 2012; 2(1): S159-S161.

[56] Pai C, Kulkarni U, Borde M, Murali S, Mrudula P, Deshmukh Y. Antibacterial activity of Tridax procumbens with special reference to nosocomial pathogen. Br J Pharm Res 2011; 1(4): 164-173.

[57] Saritha K, Rajesh A, Manjulatha K, Setty O H, Yenugu S. Mechanism of antibacterial action of the alcoholic extracts of Hemidesmus indicus (L.), R. Br. Ex Schult, Leucas aspera (Wild.), Plumbago zeylanica L., and Tridax procumbens (L.) R. Br. Ex Schult. FRONT MICROBIOL 2015; Vol 6, Article 577, 1-9. https://doi.org/10.3389/fmicb.2015.00577

[58] Dhanabalan R, Doss A, Jagadeeswari M, Balachandar S, Kezia E, Parivuguna V et al. In vitro phytochemical screening and antibacterial activity of aqueous and methanolic leaf extracts of Tridax procumbens against bovine mastitis isolated Staphylococcus aureus. Ethnobotanical Leaflets 2008; 12: 1090-1095.

[59] Bhati-Kushwaha H, Malik CP. Assessment of antibacterial and antifungal activities of silver nanoparticles obtained from the callus extracts (stem and leaf) of Tridax procumbens L. Indian J Biotechnol 2014; 13(1): 114-120.

[60] Gopalakrishnan K, Ramesh C, Ragunathan V, Thamilselvan M. Antibacterial activity of $\mathrm{Cu}_{2} \mathrm{O}$ nanoparticles on E.coli synthesized from Tridax procumbens leaf extract and surface coating with polyaniline. Dig J Nanomater Biostructures 2012; 7(2), 833-839.

[61] Harrison L, Teplow DB, Rinaldi M, Strobel G. Pseudomycins, a family of novel peptides from Pseudomonas syringae possessing broad-spectrum antifungal activity. J Gen Microbiol 1991; 137: 2857-2865.

[62] Miller CM, Miller RV, Garton-Kenny D, Redgrave B, Sears J, Condron MM et al. Ecomycins, unique antimycotics from Pseudomonas viridiflava. J Appl Microbiol 1998; 84: 937-44.

[63] Ding L, Maier A, Fiebig HH, Lin WH, Hertweck C. A family of multicyclic indolosesquiterpenes from a bacterial endophyte. Org Biomol Chem 2011; 9: 4029-31.

[64] Sharma B, Kumar P, Joshi SC. Topical treatment of dermatophytic lesion on mice (Mus musculus) model. Indian J Microbiol 2011; 51: 217-22.

[65] Naqash SY, Nazeer RA. Anticoagulant, antiherpetic and antibacterial activities of sulphated polysaccharide from Indian medicinal plant Tridax procumbens L. (Asteraceae). Appl Biochem Biotechnol 2011; 165: 902-12.

[66] Ghosh P, Biswas S, Biswas M, Dutta A, Sil S, Chatterjee S. Morphological, ethnobiological and phytopharmacological attributes of Tridax procumbens Linn.(Asteraceae): A Review. Int J Sci Res Biol Sci 2019; 6(2): 182-191.

[67] Preveena J, Bhore SJ. Identification of bacterial endophytes associated with traditional medicinal plant Tridax procumbens Linn. Anc Sci Life 2013 32(3): 173-177.

[68] Govarthanan M, Mythili R, Selvankumar T, Kamal Kannan S, Rajasekar A, Chang YC. Bioremediation of heavy metals using an endophytic bacterium Paenibacillus sp. RM isolated from the roots of Tridax procumbens. 3 Biotech 2016; 6, Article 242. https://doi.org/10.1007/s13205-016-0560-1 
[69] Kumar A, Jha PK, Kumar R, Kumar K, Sedolkar V. Antibacterial activity, phytochemical and enzyme analysis of crude extract of endophytic fungus, Alternaria sp. isolated from an ethnobotanical medicinal plant Tridax procumbens. Int J Pharma Phytochem Res 2015; 7(6): 1111-1115.

[70] Grundy SM, Cleeman JI, Daniels SR, Donato KA, Eckel RH, Franklin BA et al. Diagnosis and management of the metabolic syndrome. Circulation 2005; 112: 2735-2752.

[71] Mendrick DL, Diehl AM, Topor LS, Dietert RR, Will Y, Merril MAL et al. Metabolic syndrome and associated diseases: From the bench to the clinic. Toxicol Sci 2018; 162: 36-42.

[72] Owen JG, Reisen E. Anti-hypertensive drug treatment of patients with and the metabolic syndrome and obesity: a review of evidence, meta-analysis, post hoc and guidelines publications. Curr Hypertens Rep 2015; 17: 558-559.

[73] Heinrich M. Ethnobotany and natural products: The search for new molecules, new treatments of old diseases or a better understanding of indigenous cultures? Curr Top Med Chem 2003; 3(2): 141-154.

[74] Patridge E, Gareiss P, Kinch MS, Hoyer D. An analysis of FDA-approved drugs: natural products and their derivatives. Drug Discov Today 2016; 21: 204-207.

[75] Pareek H, Sharma S, Khajja BS, Jain K, Jain GC. Evaluation of hypoglycemic and anti-hyperglycemic potential of Tridax procumbens (Linn.). BMC Complement Altern Med 2009; 9: Article No. 48, https://doi.org/10.1186/1472-6882-9-48

[76] Bhagwat DA, Killedar SG, Adnaik RS. Anti-diabetic activity of leaf extract of Tridax procumbens. Int J Green Pharm 2008; 2(2): 126-128.

[77] Petchi RR, Parasuraman S, Vijay C. Antidiabetic and antihyperlipidemic effects of an ethanolic extract of the whole plant of Tridax procumbens (Linn.) in streptozotocin-induced diabetic rats. J Basic Clin Pharm 2013; 4(4), 88-92.

[78] Petchi RR, Vijaya C, Parasuraman S. Antidiabetic activity of polyherbal formulation in streptozotocin - nicotinamide induced diabetic Wistar rat. $J$ Tradit Complement Med 2014; 4(2): 108-117.

[79] Ali MS, Jahangir M, ul Hussan SS, Choudhary MI. Inhibition of $\alpha$-glucosidase by oleanolic acid and its synthetic derivatives. Phytochemistry 2002; 60(3): 295-299.

[80] Sonawane A, Srivastava RS, Sanghavi N, Malode Y, Chavan B. Anti-diabetic activity of Tridax procumbens. Journal of Scientific and Innovative Research 2014; 3(2): 221-226.

[81] Desai GS, Desai SV, Gavaskar RS, Mulabagal V, Wu Y, Mathews ST. Blood glucose-lowering effect of T. procumbens L. A pilot clinical study in individuals with type 2 diabetes. Phytother Res 2015; 29(9): 1404-1411.

[82] Colosia AD, Palencia R, Khan S. Prevalence of hypertension and obesity in patients with type 2 diabetes mellitus in observational studies: a systematic literature review. Diabetes Metab Syndr Obes 2013; 6: 327-338.

[83] Adjagba M, Awede B, Nondichao K, Lagnika L, Osseni R, Darboux R et al. Antihypertensive activity of different fractions of Tridax procumbens crude aqueous extract in Wistar rats. J Physiol Pharmacol Adv 2015; 5(9): 713-719.

[84] Salahdeen HM, Idowu GO, Salami SA, Murtala BA, Alada AA. Mechanism of vasorelaxation induced by Tridax procumbens extract in rat thoracic aorta. J Intercult Ethnopharmacol 2016; 5(2): 174-179.

[85] Salahdeen HM, Adebari AO, Murtala BA, Alada AR. Potassium channels and prostacyclin contribute to vasorelaxant activities of Tridax procumbens crude aqueous leaf extract in rat superior mesenteric arteries. Afr J Med Med Sci 2015; 44(1): 5-19.

[86] Salahdeen HM, Idowu GO, Yemitan OK, Murtala BA, Alada AR. The relaxant actions of ethanolic extract of Tridax procumbens (Linn.) on rat corpus cavernosum smooth muscle contraction. J Basic Clin Physiol Pharmacol 2015; 26(2): 211-16.

[87] Priya VP, Radhika K, Rao SA. In vitro anti-cancer activity of aqueous and acetone extracts of Tridax procumbens leaf on PC 3 cell lines. Int J Pharm Pharm Sci 2011; 3(4): 1-4.

[88] Sankaranarayanan S, Bama P, Sathyabama S, Bhuveneswari N. Anticancer compound isolated from the leaves of Tridax procumbens against human lung cancer cell A-549. Asian J Pharm Clin Res 2013; 6(2): 91-96.

[89] Manjamalai A, Kumar MJM, Grace VMB. Essential oil of Tridax procumbens L induces apoptosis and suppresses angiogenesis and lung metastasis of the B16F-10 cell line in C57BL/6 mice. Asian Pac J Cancer Prev 2012; 13(11): 5887-5895.

[90] Devi DR, Sandhya P, Subhashri S, Hari BNV. Tridax procumbens: A herbal nano formulation for cancer therapy. Asian J Chem 2014; 26(12): 37193723.

[91] David S, Hamilton JP. Drug-induced Liver Injury. US Gastroenterol Hepatol Rev 2020; 6: 73-80.

[92] Schoepfer AM, Engel A, Fattinger K, Marbet UA, Criblez D, Reichen J et al. Herbal does not mean innocuous: ten cases of severe hepatotoxicity associated with dietary supplements from Herbalife products. J Hepatol 2007; 47(4): 521-526.

[93] Wagha SS, Shinde GB. Antioxidant and hepatoprotective activity of Tridax Procumbens Linn, against paracetamol induced hepatotoxicity in male albino rats. Adv Stud Biol 2010; 2(3): 105-112.

[94] Patel NA, Vaidya SK, Kumar S, Prasad AK, Bothara SB. Antioxidant and hepatoprotective activity of extracts of flowers of Tridax Procumbens Linn, against D-galectosamine induced hepatotoxicity in male wister albino rats. Indo American J Pharm Res 2014; 4(9): 3712-3720.

[95] Ikewuchi JC. An aqueous extract of the leaves of Tridax procumbens Linn (Asteraceae) protected against carbon tetrachloride induced liver injury in wistar rats. Pac J Sci Technol 2012; 13(1): 519-527.

[96] Sagheer R, Singh R, Nasibullah M, Ansari JA, Srivastava SK, Mahd AA. Exploration of hepatoprotective potential of methanolic extract of Tridax procumbens against isoniazid-rifampicin induced toxicity in albino rats. J Pharmacogn Phytochem 2018; 7(3): 384-390.

[97] Wagha SS, Shinde GB. Investigation of hepatoprotective and antioxidant activity of Tridax procumbens Linn. (Asteraceae) extract against rifampicin induced hepatotoxicity in male albino rats. Materials Today: Proceedings 2018; 5(10): 22605-22613.

[98] Ravikumar V, Shivashangari KS, Devaki T. Hepatoprotective activity of Tridax procumbens against D-galactosamine/lipopolysaccharide-induced hepatitis in rats. J Ethanopharmacol 2005; 101: 55-60.

[99] Ravikumar V, Shivashangari KS, Devaki T. Effect of Tridax procumbens on liver antioxidant defense system during lipopolysaccharide-induced hepatitis in D-galactosamine sensitised rats. Mol Cell Biochem 2005; 269: 131-136.

[100] Nash LA, Sullivan PJ, Peters SJ, Ward WE. Rooibos flavonoids, orientin and luteolin, stimulate mineralization in human osteoblasts through the Wnt pathway. Mol Nutr Food Res 2015; 59: 443-53

[101]Al Mamun MA, Islam K, Alam MJ, Khatun A, Alam MM, Al-Bari MA et al. Flavonoids isolated from Tridax procumbens (TPF) inhibit osteoclasts differentiation and bone resorption. Biol Res 2015; 48: 51.

[102] Al Mamun MA, Hosen MJ, Khatun A, Alam MM, Al-Bari MA. Tridax procumbens flavonoids: a prospective bioactive compound increased osteoblast differentiation and trabecular bone formation. Biol Res (2017); 50:28.

[103] Al Mamun MA, Asim MMH , Sahin MAZ, Al Bari MAA. Flavonoids compounds from Tridax procumbens inhibit osteoclast differentiation by downregulating c-Fos activation. J Cell Mol Med (2020). https://doi.org/10.1111/jcmm.14948.

[104]Wing M, Medicinal plants: A source of anti-parasitic secondary metabolites. Molecules 2012; 17(11): 12771-91.

[105] Martín Quintal Z, del Rosario García Miss M, Mut Martín M, Matus Moo A, Torres Tapia W, Peraza Sánchez SR. The leishmanicidal effect of (3S)16,17-didehydrofalcarinol, an oxylipin isolated from Tridax procumbens, is independent of NO production. Phytother Res 2010; 24(7): 1004-8.

[106] Appiah-Opong R, Nyarko AK, Dodoo D, Gyang FN, Koram KA, Ayisi NK. Antiplasmodial activity of extracts of Tridax procumbens and Phyllanthus amarus in in vitro Plasmodium falciparum culture system. Ghana Med J 2011; 45(4): 143-150.

[107]Gamboa-Leon R, Vera-Ku M, Peraza-Sanchez SR, Ku-Chulim C, Horta-Baas A, Rosado- Vallado M. Antileishmanial activity of a mixture of Tridax procumbens and Allium sativum in mice. Parasite 2014; 21: 15. doi: 10.1051/parasite/2014016 